\title{
江戸城作事に於ける大工以下諸職人について
}

\author{
正会員 西和 夫*
}

1. 江戸時代と職人

江戸時代は職人の時代とさえ呼ばれる注ど職人の存在 が大きかった。その中心をなしていたのは，大工をはじ め，左官・鐉治等建築作事関係の職人達であった。

この職人は，德川幕府と直接結びついていたいわゆる 御用聞職人と, その下にいた一般の平職人とに分けるこ とができる。前者のうち建築作事関係の職人達は幕府の

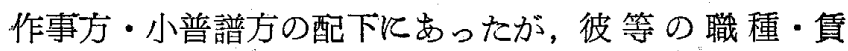
銀，労㗢条件等を示す資料として江戸城造営に関する諸 記録〔註・1〕及び，作事方大棟梁甲良家に伝わる作事見 積資料ともいうべき本途帳〔洼・2〕とがある。

本報告は，これ等の史料沉よる江戸城作事に於ける大 工をはじめとする諸職人についての考察である。

\section{2. 江戸城の工事}

江戸城殿諸舎は，江戸時代を通じて度々の焼失・再建 をくり返し，增改築，修理を合めればいっも何かしら工 事を行っていたとも言えるほどで，作事関係の職人が常 《必要とされた。

又, 再建要した期間はどの場合も8〜12 ケ月ほど で，その建物規模の大きいとと，工事が最高級の，実に 念入りなるのだといろ点等を考党ると警くべき早さであ る。これを可能にするためには多数の瞕人が有効に使役 されたに違いなく, その背景には建築作事組織の整備, 施工及び積算技術の進歩が要求された違いない。

\section{3. 作事組織の中の職人}

例えば弘化度本丸工事の記録によれば，工事総督たる 老中以下，作事方だけでも「掛り員」として141 人の名 があげられているほど大きな組織があった。

この中，工事施工に関しては，

作事奉行 $\rightarrow$ 御大工頭 $\rightarrow$ 大棟梁 $\rightarrow$ 諸職棟梁 $\rightarrow$ 諸職人とい ろ系列をとり出すことができる。更に，一般の平職人と の関係は,

諸職棟梁 $\rightarrow$ 諸職照煎 $\rightarrow$ 諸職平職人

という形で関連をもっていたと思われる。

\section{4. 職人の種類 (職種)}

江戸城工事記録及び本途帳には次の如き職種が見られ る。

大工・䧓物大工・穴掘大工・船大工・穴蔵大工・木

* 東京工業大学大学院生
挽・大伐 (大鋸) - 通挽・杣・取木・鍛治・錺師・壁方 - 石灰摺 - 塗師 - 箔押 - 絵師 - 屋根方, 瓦方 - 建具方 張付師・桶方・石方 - 砂利方 - 土方 - 足代方, 人足方 ( 小使人足・湯小屋人足) - 翠篻師・畳方・小細工方・(小 買物方)

小買物とは，筆紙畦等の日用品等の買入れを仕事とし たもので，職人ではなく，商人として考党るべきもの。 壁方には左官，小舞搔，土こ放含めてよからう。取木 は聞きなれ奴職名だが，本途帳の記事から推すと，幕腑 御用材木収蔵場所の猿江材木蔵なぞと於て，江戸城造営 の際, 入用材木を取り出し, 水路を通じて作事現場梞で 用材を送りとどけたるので，舟積みといかが送りとがあ った。

\section{5. 大棟梁と各種棟梁の関係}

各職瑓梁は, あらかじめ今後の工事の際はこの值段で 請負う(これは本途直段という）という契約を大棟梁( 名目上は作事奉行）と結んで拓く。(これを本途請負) この本途直段をまとめた帳簿（本途帳）を大棟梁が保持 し，その後の施工・積算資料として用いる。工事漈し ては本途請負を通じて施工させた。（な㧍，本途帹は幕 府財政担当の勒定方でる用いた。）(圾・3〕

\section{6. 職人の賃銀}

弘化度本丸工事の際の賃銀は, 大工 : 手間 4.4 多/人, 飯料 4.2 升/人, 䧓物大工: 1.75 多/人. 1.66 升/人, 木 挽: 4.9 多/人・ 4.6 平/人，等で，すべて本途賃銀を基 準にし，それに割増を加学るという方式で算出されてい る。

火炎や飢飳によって米価や貨銀が変動する。多数つ職 人を要する江戸城作事に於ては, その費用見積当って これイどう対処したか。本途という基準值を用いること こそ，その解決策であったと思われる。[柱・4]

な扮，安政 3 年の諸職公定貨銀〔註・5〕等の諸史料に より，当時の瞕種刉による貫銀格差や平職人との賃銀比 較等を知るととができる。

[壕]

1 5 東京市史稿・皇城篇・市街篇（東京市）

2 東京都立日比谷図書館東宗誌料所収

3 日本財政経済史料(財政経済学会・大 11)

4 江戸城作事淤ける大工その他 貨銀について（西・学 会関東支部研究発表会梗概集・1964.5) 